\title{
Inflammation and oxidative stress transcription profiles due to in vitro supply of methionine with or without choline in unstimulated blood polymorphonuclear leukocytes from lactating Holstein cows
}

\author{
V. Lopreiato, ${ }^{1}$ M. Vailati-Riboni, ${ }^{2}$ A. Bellingeri, ${ }^{1}$ I. Khan, ${ }^{3}$ G. Farina, ${ }^{4}$ C. Parys,${ }^{5}$ and J. J. Loor ${ }^{2 *}$ \\ ${ }^{1}$ Department of Animal Sciences, Food and Nutrition, Faculty of Agriculture, Food and Environmental Science, \\ Università Cattolica del Sacro Cuore, 29122 Piacenza, Italy \\ ${ }^{2}$ Mammalian NutriPhysioGenomics, Department of Animal Sciences and Division of Nutritional Sciences, University of Illinois, Urbana 61801 \\ ${ }^{3}$ Faculty of Animal Husbandry and Veterinary Sciences, University of Agriculture, Peshawar, 25120, Pakistan \\ ${ }^{4}$ Department of Veterinary Science for Health, Animal Production and Food Safety, Università degli Studi di Milano 20122, Milano, Italy \\ ${ }^{5}$ Evonik Nutrition \& Care GmbH, Hanau-Wolfgang 63457, Germany
}

\section{ABSTRACT}

Neutrophils are the most important polymorphonuclear leukocytes (PMNL), representing the front-line defense involved in pathogen clearance upon invasion. As such, they play a pivotal role in immune and inflammatory responses. Isolated PMNL from 5 mid-lactating Holstein dairy cows were used to evaluate the in vitro effect of methionine (Met) and choline (Chol) supplementation on mRNA expression of genes related to the Met cycle and innate immunity. The target genes are associated with the Met cycle, cell signaling, inflammation, antimicrobial and killing mechanisms, and pathogen recognition. Treatments were allocated in a $3 \times 3$ factorial arrangement, including 3 Lys-to-Met ratios (L:M, 3.6:1, 2.9:1, or 2.4:1) and 3 levels of supplemental Chol $(0,400$, or $800 \mu \mathrm{g} / \mathrm{mL})$. Three replicates per treatment group were incubated for $2 \mathrm{~h}$ at $37^{\circ} \mathrm{C}$ and $5 \%$ atmospheric $\mathrm{CO}_{2}$. Both betaine-homocysteine $S$-methyltransferase and choline dehydrogenase were undetectable, indicating that PMNL (at least in vitro) cannot generate Met from Chol through the betaine pathway. The PMNL incubated without Chol experienced a specific state of

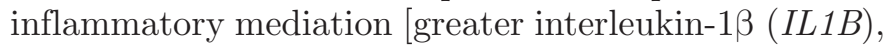
myeloperoxidase $(M P O), I L 10$, and IL6] and oxidative stress [greater cysteine sulfinic acid decarboxylase $(C S A D)$, cystathionine gamma-lyase $(C T H)$, glutathione reductase $(G S R)$, and glutathione synthase $(G S S)]$. However, data from the interaction L:M $\times$ Chol indicated that this negative state could be overcome by supplementing additional Met. This was reflected in the upregulation of methionine synthase $(M T R)$ and toll-like receptor 2 (TLR2); that is, pathogen detection ability. At the lowest level of supplemental Chol, Met

Received January 31, 2019.

Accepted June 28, 2019

*Corresponding author: jloor@illinois.edu downregulated $G S S, G S R, I L 1 B$, and $I L 6$, suggesting it could reduce cellular inflammation and enhance antioxidant status. At $400 \mu \mathrm{g} / \mathrm{mL}$ Chol, supplemental Met upregulated PMNL recognition capacity [higher TLR4 and L-selectin $(S E L L)$ ]. Overall, enhancing the supply of methyl donors to isolated unstimulated PMNL from mid-lactating dairy cows leads to a low level of PMNL activation and upregulates a cytoprotective mechanism against oxidative stress. Enhancing the supply of Met coupled with adequate Chol levels enhances the gene expression of PMNL pathogen-recognition mechanism. These data suggest that Chol supply to PMNL exposed to low levels of Met effectively downregulated the entire repertoire of innate inflammatory-responsive genes. Thus, Met availability in PMNL during an inflammatory challenge may be sufficient for mounting an appropriate biologic response.

Key words: innate immune function, inflammation, neutrophil, methyl donor, amino acid

\section{INTRODUCTION}

The nutritional status of dairy cows is tightly correlated with maintenance of proper immune function and health. The immune system not only benefits greatly from proper nutrition but, indirectly, proper nutrition prepares the cow for periods of stress, reducing adverse effects and enhancing recovery from them (Ingvartsen and Moyes, 2013; Loor et al., 2013). Methionine (Met) and choline (Chol) are nutritionally important methyl donors with functional properties beyond methyl group transfer. For instance, Zhou et al. (2016a) and Batistel et al. (2018) reported that cows receiving rumenprotected Met to obtain a Lys-to-Met ratio of 2.8:1 in metabolizable protein during the periparturient period had enhanced neutrophil phagocytosis and oxidative burst and better systemic indicators of oxidative stress and inflammation. In rodents experiencing an oxida- 
tive challenge, Chol supplementation suppressed oxidative stress and attenuated inflammation (Mehta et al., 2010). Although various studies have demonstrated that enhanced supply of rumen-protected Met benefits health status, metabolic profile, and lactation performance (Osorio et al., 2014; Zhou et al., 2016b,c), supply of Chol alone was ineffective in helping alleviate inflammation in high-yielding dairy cows (Zhou et al., 2016a). This effect may have contributed to the lack of benefit in terms of production outcomes (Zhou et al., 2016c; Zenobi et al., 2018).

Specific to immune cells, it is noteworthy that Met coupled with Chol supplementation has been associated with an improvement of polymorphonuclear leukocyte (PMNL) responses to whole-blood LPS stimulation (Vailati-Riboni et al., 2017). At the molecular level, data on gene expression indicated a lower inflammation response and overall better redox status in PMNL during the transition period in response to Met and Chol supply (Zhou et al., 2018). Because of these in vivo data indicating differences in biological activity of Met or Chol on innate immune function, it is important to study more closely the response of immune cells to these methyl donors. This is particularly important in the case of Chol because a recent study indicated low intestinal bioavailability of rumen-protected Chol (de Veth et al., 2016). Thus, a side-by-side comparison of Met and Cho using an in vitro system would generate valuable data in terms of efficacy. Because of the recognition that certain metabolic organs also are immune responsive, data from this type of study would also help clarify the potential link between the immune and metabolic responses, especially in early lactation ( $\mathrm{Li}$ et al., 2015; Du et al., 2018; Zhu et al., 2019).

The general hypothesis was that Met and Chol are partly involved in regulating blood-derived PMNL function through a direct or indirect effect on the inflammatory response, antioxidant status, and immune mediation pathways. Thus, we evaluated the effect of different ratios of Met and Chol supplementation in vitro on the mRNA expression of genes related to the Met cycle, cell signaling, inflammation, antimicrobial mechanisms, immune mediators, and adhesion molecules in short-term cultures of PMNL isolated from mid-lactating Holstein cows.

\section{MATERIALS AND METHODS}

\section{Animal Handling and Blood Sampling}

Five Holstein cows were selected from the University of Illinois Dairy unit herd (Urbana, IL). Cows were in mid-lactation (153 \pm 5 DIM), had an average production in the week of sampling of $34.63 \pm 2.73 \mathrm{~kg} / \mathrm{d}$, and were deemed healthy (e.g., absence of clinical scenarios, not treated during the current lactation, $\mathrm{SCC}<100,000$ cells $/ \mathrm{mL}$ ). Cows were housed in a freestall barn with sand-bedded cubicles and access to a concrete lot, where the feed bunk was located. Cows were fed once a day, at $0700 \mathrm{~h}$, a corn silage-based TMR diet. Milking was done 3 times a day, at 0500, 1200, and $1900 \mathrm{~h}$. Blood was collected from the jugular vein at $0600 \mathrm{~h}$, before feeding, into Vacutainer tubes (BD Vacutainer, Becton Dickinson and Co., Franklin Lakes, NJ), containing 1.5 $\mathrm{mL}$ of ACD solution A (trisodium citrate, $22.0 \mathrm{~g} / \mathrm{L}$; citric acid, $8.0 \mathrm{~g} / \mathrm{L}$; and dextrose $24.5 \mathrm{~g} / \mathrm{L}$ ). From each animal, 15 tubes were collected, for a total of 120 to 150 $\mathrm{mL}$ of blood. Blood was immediately placed on ice and transported to the laboratory for immediate isolation of PMNL within 40 min from the time of sampling.

\section{PMNL Isolation}

The PMNL were isolated based on procedures previously described (Abdelmegeid et al., 2017). Briefly, samples were centrifuged at $600 \times g$ for $30 \mathrm{~min}$ at $4^{\circ} \mathrm{C}$. The plasma, buffy coat, and approximately one-third of the red blood cells were removed and discarded. The remaining sample was poured into a $50-\mathrm{mL}$ conical tube (Fisher Scientific, Pittsburgh, PA). Twenty-five milliliters of deionized water at $4^{\circ} \mathrm{C}$ was added to lyse the red blood cells, followed by addition of $5 \mathrm{~mL}$ of $5 \times$ PBS at $4^{\circ} \mathrm{C}$ to restore an iso-osmotic environment. Samples were centrifuged at $200 \times g$ for $10 \mathrm{~min}$ at $4^{\circ} \mathrm{C}$ and the supernatants decanted. The pellet was washed with $10 \mathrm{~mL}$ of $1 \times$ PBS and centrifuged for $5 \mathrm{~min}(200 \times g$ at $4^{\circ} \mathrm{C}$ ) and the supernatants decanted. Eight milliliters of deionized water at $4^{\circ} \mathrm{C}$ was added, followed by addition of $2 \mathrm{~mL}$ of $5 \times \mathrm{PBS}$ at $4^{\circ} \mathrm{C}$. Samples were centrifuged at $500 \times g$ for $5 \mathrm{~min}$ at $4^{\circ} \mathrm{C}$ and the supernatant decanted. Two subsequent washings using $10 \mathrm{~mL}$ of $1 \times$ PBS at $4^{\circ} \mathrm{C}$ were performed with samples centrifuged at 500 $\times g$ for 5 min at $4^{\circ} \mathrm{C}$ and supernatants decanted. The final neutrophil pellets from 5 animals were then mixed together to obtain a homogeneous pool, washed again with $10 \mathrm{~mL}$ of $1 \times \mathrm{PBS}$ at $4^{\circ} \mathrm{C}$, centrifuged at $500 \times \mathrm{g}$ for $5 \mathrm{~min}$ at $4^{\circ} \mathrm{C}$, and the supernatant decanted. Before incubation with Met and Chol, a $50-\mu \mathrm{L}$ aliquot of the neutrophil pool was incubated for $15 \mathrm{~min}$ on ice with $100 \mu \mathrm{L}$ of the primary antibody $\mathrm{CH} 138 \mathrm{~A}$ solution (15 $\mu \mathrm{g} / \mathrm{mL}$ in $1 \times \mathrm{PBS})$. The aliquot was then washed twice with $2 \mathrm{~mL}$ of $1 \times$ PBS and incubated for another $15 \mathrm{~min}$ on ice, protected from light, with $50 \mu \mathrm{L}$ of secondary antibody solution phycoerythrin $(\mathbf{P E} ; 4 \mu \mathrm{g} / \mathrm{mL}$ in $1 \times$ PBS), and $50 \mu \mathrm{L}$ of propidium iodide (PI; $50 \mu \mathrm{g} / \mathrm{mL}$ ) before reading with a flow cytometer (BD LSR II Flow Cytometry Analyzer, BD Biosciences, San Jose, CA). A total of 10,000 events were read. The PMNL were 
identified by a combination of morphology (forward vs. side scatter plot) and labeling with PE (10020-09S, Southern Biotech, Birmingham, AL) (PE-positive cells, via scatter plots, PE intensity vs. side scatter). From this population, PI-positive cells were deemed dead (histogram; PI intensity vs. cell count). The PMNL purity was greater than $80 \%$ and viability greater than $90 \%$.

\section{Incubation and Treatments}

The isolated pool of PMNL was diluted to a final concentration of $6 \times 10^{6}$ cells $/ \mathrm{mL}$ with warm $\left(37^{\circ} \mathrm{C}\right)$, methionine-free, incubation medium (RPMI 1640, Gibco, Thermo Fisher, Waltham, MA) and 8\% fetal bovine serum (Sigma-Aldrich, St. Louis, MO) previously heat-inactivated. From the diluted pool, aliquots of $1 \mathrm{~mL}$ were incubated in 14-mL Falcon tubes (Fisher Scientific, Hampton, NH), with a snap-cap design to allow airflow, and allocated to each experimental group. The PMNL were incubated in a $3 \times 3$ factorial design, with ratios of L:M of $3.6: 1,2.9: 1$, or 2.4:1 calculated based on medium concentration of lysine, and 3 levels of supplemental Chol (0, 400, and $800 \mu \mathrm{g} / \mathrm{mL}$ ) over the basal level of Chol already present in the medium ( $3 \mathrm{mg} / \mathrm{L}$, as choline chloride). For each treatment combination, 3 tubes were incubated. Both L-methionine (Sigma-Aldrich) and Chol, as choline chloride (SigmaAldrich), were added to the test tubes from stock solutions previously prepared using the incubation medium as a diluent. Incubations lasted $2 \mathrm{~h}$ at $37^{\circ} \mathrm{C}$ in a sterile incubator with a controlled $\mathrm{CO}_{2}(5 \%)$ atmosphere.

\section{RNA Extraction}

After incubation, PMNL were pelleted by centrifugation and the supernatant collected for further analysis. Total RNA was extracted using Qiazol reagent (Qiagen, Hilden Germany). The cell pellet was placed in $1 \mathrm{~mL}$ of Qiazol and tissue was homogenized with a Bead Beater 16 (Biospec, Bartlesville, OK), using two 30-s cycles of the homogenizer at full speed, and placed on ice for 1 min after homogenization. Homogenized samples were centrifuged to remove any remaining cell debris. Chloroform was then added to the homogenized sample, centrifuged at $16,000 \times g$ for $15 \mathrm{~min}$ at $4^{\circ} \mathrm{C}$, and the aqueous phase removed carefully. Precipitation of RNA was achieved with the addition of ethanol (Decon Labs Inc., King of Prussia, PA), and the subsequent RNA pellet was washed and cleaned using miRNeasy mini spin columns (Qiagen). Genomic DNA was removed during purification with on-column DNase digestion (Qiagen). The RNA concentration was measured using a NanoDrop ND-1000 spectrophotometer (NanoDrop
Technologies, Wilmington, DE), and RNA quality was assessed using a 2100 Bioanalyzer (Agilent Technologies, Santa Clara, CA). All samples had an RNA integrity value $>8.0$.

\section{cDNA Synthesis and qPCR}

Genes selected for transcript profiling in PMNL are associated with methionine cycle (ALDH $7 A 1, B H M T$, CHDH, MAT1A, MAT2A, MTR, PEMT, SAHH), the transsulfuration pathway and antioxidant system (CBS, CDO1, CSAD, CTH, GCLC, GPX1, GSR, GSS), cytokines and inflammation signaling (IL1B, IL10, IL6, IRAK1, NFKB1, NR3C1), antimicrobial function, pattern recognition, and adhesion (CXCR1, HLAA, LYZ, MPO, SELL, SOD1, TLR2, TLR4), and apoptosis and cellular stress (BAX, BCL2, HSP 70$)$. Sequence information for all primers used can be found elsewhere (Fear and Hansen, 2011; Abdelmegeid et al., 2017). A portion of the RNA was diluted to $100 \mathrm{ng} / \mu \mathrm{L}$ using DNase/RNase-free water before reverse transcription. Then, cDNA was synthesized using $100 \mathrm{ng}$ of RNA, 1 $\mu \mathrm{g}$ of dT18 (Operon Biotechnologies, Huntsville, AL), 1 $\mu \mathrm{L}$ of $10 \mathrm{mmol} / \mathrm{L}$ dNTP mix (Invitrogen Corp., Carlsbad, CA), $1 \mu \mathrm{L}$ of random primers (Invitrogen Corp.), and $10 \mu \mathrm{L}$ of DNase/RNase-free water. The mixture was incubated at $65^{\circ} \mathrm{C}$ for $5 \mathrm{~min}$ and kept on ice for 3 min. A total of $6 \mu \mathrm{L}$ of master mix composed of 4.5 $\mu \mathrm{L}$ of $5 \times$ First-Strand Buffer, $1 \mu \mathrm{L}$ of $0.1 M$ dithiothreitol (DTT), $0.25 \mu \mathrm{L}(50 \mathrm{U})$ of SuperScript III RT (Invitrogen Corp.), and $0.25 \mu \mathrm{L}$ of RNase Inhibitor (10 U, Promega, Madison, WI) was added. The reaction was performed in an Eppendorf Mastercycler Gradient (Eppendorf, Hamburg, Germany) using the following temperature program: $25^{\circ} \mathrm{C}$ for $5 \mathrm{~min}, 50^{\circ} \mathrm{C}$ for $60 \mathrm{~min}$, and $70^{\circ} \mathrm{C}$ for $15 \mathrm{~min}$. The cDNA was then diluted $1: 4$ (vol/vol) with DNase/RNase-free water.

Quantitative PCR (qPCR) was performed using 4 $\mu \mathrm{L}$ of diluted cDNA combined with $6 \mu \mathrm{L}$ of a mixture composed of $5 \mu \mathrm{L}$ of SYBR Green master mix (Applied Biosystems, Foster City, CA), $0.4 \mu \mathrm{L}$ each of $10 \mu M$ forward and reverse primers, and $0.2 \mu \mathrm{L}$ of DNase/ RNase-free water in a MicroAmp Optical 384-Well Reaction Plate (Applied Biosystems). Each sample was run in triplicate and a 6-point relative standard curve plus no-template control were used. The reactions were performed in an ABI Prism 7900 HT SDS instrument (Applied Biosystems, CA) using the following conditions: 2 min at $50^{\circ} \mathrm{C}, 10 \mathrm{~min}$ at $95^{\circ} \mathrm{C}, 40$ cycles of $15 \mathrm{~s}$ at $95^{\circ} \mathrm{C}$ (denaturation), and $1 \mathrm{~min}$ at $60^{\circ} \mathrm{C}$ (annealing + extension). The presence of a single PCR product was verified by the dissociation protocol using incremental temperatures to $95^{\circ} \mathrm{C}$ for $15 \mathrm{~s}$ plus $65^{\circ} \mathrm{C}$ for $15 \mathrm{~s}$. Data were calculated with the 7900 HT Sequence Detection 
Systems Software (version 2.2.1, Applied Biosystems). The final data were normalized using the geometric mean of 3 internal control genes: GAPDH, RPS9, and $U X T$. These internal control genes were previously confirmed as suitable for PMNL gene expression analysis (Moyes et al., 2014). Details of the qPCR performance can be found in the Supplemental Table S1 (https:// doi.org/10.3168/jds.2019-16413). Expression of BHMT, CHDH, MAT1A, and PEMT was deemed undetectable (Supplemental Table S1).

\section{Supernatant Analysis}

The collected supernatant was used for analysis of IL-1 $\beta$, IL-6, and tumor necrosis factor- $\alpha$ (TNF $\boldsymbol{\alpha})$ concentrations. The quantification was performed using bovine-specific ELISA kits according to the manufacturer's specifications (IL-1 $\beta$ and IL6, Thermo Fisher; TNFo, Kingfisher Biotech Inc., St. Paul, MN).

\section{Statistical Analysis}

After normalization with the geometric mean of the internal control genes, the triplicate averages of the qPCR data were $\log _{2}$ transformed before statistical analysis to obtain a normal distribution. Statistical analysis of both gene expression and supernatant cytokines was performed in SAS (SAS Institute Inc., Cary, NC). Data were subjected to ANOVA and analyzed with PROC MIXED. The statistical model included L:M ratio (3.6:1, 2.9:1, 2.4:1), supplemental Chol (0, $400,800 \mu \mathrm{g} / \mathrm{mL}$ ), and their interactions $(\mathrm{L}: \mathrm{M} \times \mathrm{Chol})$ as fixed effects. Normality of the residuals was tested via PROC UNIVARIATE in SAS. All observations were normally distributed. The Kenward-Roger statement was used to compute the denominator degrees of freedom. Orthogonal contrasts were used to determine the linear or quadratic effect of L:M and Chol overall. Data were considered significant at $P \leq 0.05$, and tendencies were determined at $P \leq 0.10$ using the PDIFF statement in SAS.

Principal component analysis (PCA) using the PRINCOMP procedure in SAS was used to determine components that accounted for most of the total variation within gene expression of isolated unstimulated PMNL in vitro incubated with a L:M ratio of $3.6: 1$, $2.9: 1$, or $2.4: 1$, and 3 levels of supplemental Chol (0, 400 , or $800 \mu \mathrm{g} / \mathrm{mL}$ ). The PCA is an unsupervised clustering technique that can be used to examine the intrinsic variation in a data set and to reduce the dimensionality or complexity of the data. Score plots were used to highlight similarities and differences among the data sets, and loading vectors revealed which variables (genes) were most responsible for the variation within the principal components (PC) of the data set. After calculation of eigenvalues (the amount of the total variance explained), 3 scatterplots according to treatment (L:M, Chol, and L:M $\times$ Chol) in the first $2 \mathrm{PC}$ scores were created. In addition, to evaluate differences or similarities between treatments within each $\mathrm{PC}$, scores were subjected to ANOVA using PROC GLM of SAS, assuming a cut-off $P$-value $<0.05$. Furthermore, averages by treatment combinations $(\mathrm{L}: \mathrm{M} \times \mathrm{Chol})$ of the $\log _{2}$ normalized mRNA relative abundance were imported into Genesis v. 1.8.1 (Sturn et al., 2002) for hierarchical clustering. Both genes and treatment groups were clustered using complete linkage as agglomeration rule and Euclidian distances.

\section{RESULTS}

For ease of interpretation, gene expression estimates and standard errors reported in Table 1 and Figures 1, 2 , and 3 were back-transformed.

\section{Methionine Cycle}

Among genes related to the Met cycle, $A L D H^{r} 7 A 1$ and MTR were affected overall by L:M $(P<0.05$; Table 1). For both genes, greater expression was detected with the increase in Met supply, with peak expression at a ratio of 2.4:1 [linear $($ Lin),$P<0.05$ ]. A quadratic (Quad) effect of Chol was detected for MAT2A (Quad, $P<0.05$ ) where Chol at $400 \mu \mathrm{g} / \mathrm{mL}$ led to upregulation compared with Chol at $0 \mu \mathrm{g} / \mathrm{mL}$ (Table 1). Reducing the L:M ratio from 3.6:1 to 2.9:1 resulted in upregulation of $S A H H$ expression $(P<0.05)$, but when L:M decreased to 2.4:1, the expression of $S A H H$ was intermediate between that at 3.6:1 and 2.9:1 of L:M (Table 1).

\section{Transsulfuration Pathway}

Expression of $C D O 1$ was quadratically affected by increasing levels of Met (Quad, $P<0.05$; Table 1). A similar response was obtained with Chol supplementation, with $C D O 1$ expression $(P<0.05)$ reaching a peak at a concentration of $400 \mu \mathrm{g} / \mathrm{mL}$ compared with 800 $\mu \mathrm{g} / \mathrm{mL}$ (Quad, $P<0.05$ ). For GPXI, an L:M ratio of 2.4:1 led to greater expression than that at 2.9:1 $(P<$ 0.05; Table 1).

The expression of CSAD, CTH, GSR, and GSS genes was affected overall by Chol $(P \leq 0.05$; Table 1$)$. Increasing levels of Chol resulted in downregulation of these genes (Lin, $P<0.05$ ), with the lowest expression occurring at $800 \mu \mathrm{g} / \mathrm{mL}$ compared with that at 0 and 
DAIRY COW NEUTROPHILS AND METHYL DONORS

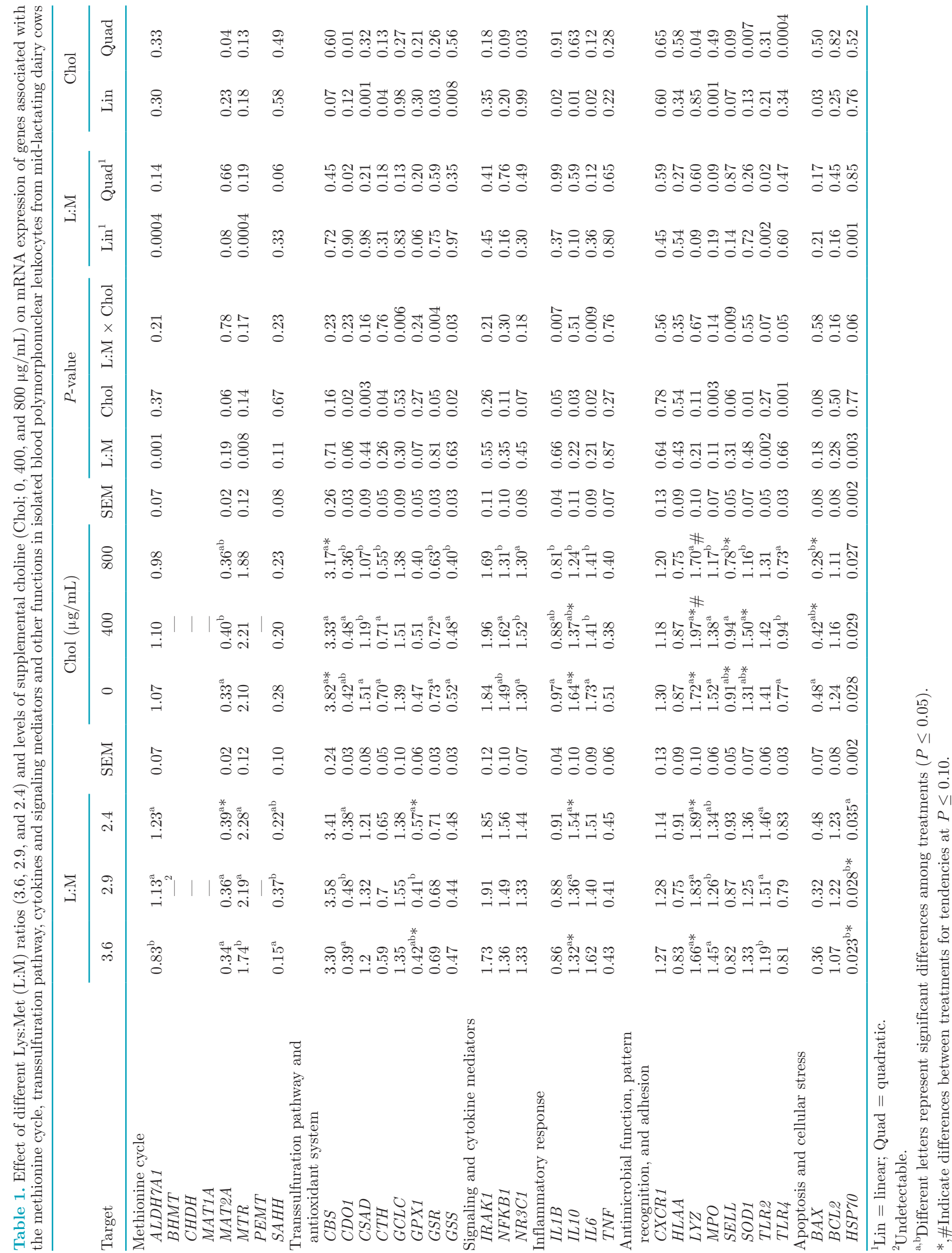



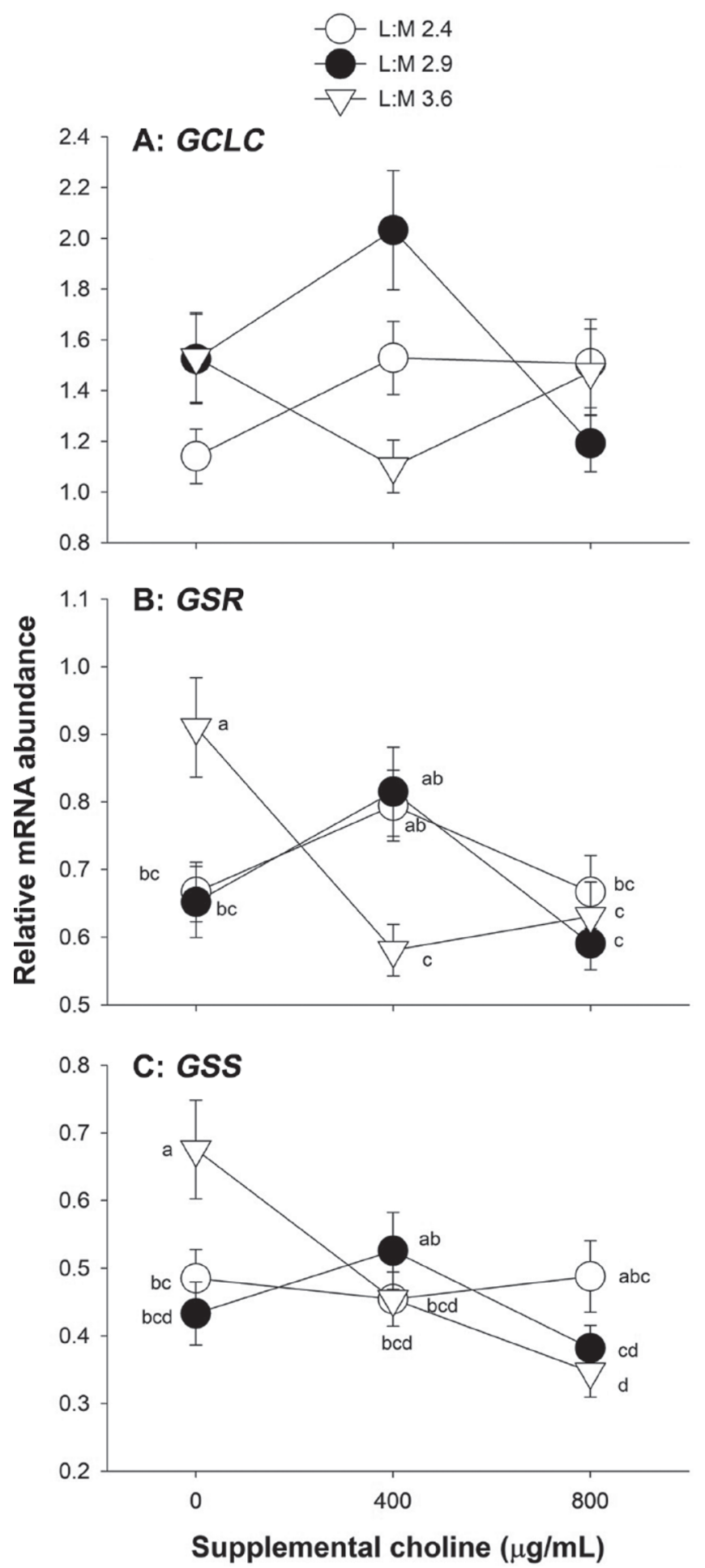

Figure 1. Interaction between Lys:Met (L:M) ratio (3.6, 2.9, 2.4) and supplemental choline (Chol; 0,400 , and $800 \mu \mathrm{g} / \mathrm{mL}$ ) in vitro on mRNA expression of genes associated with the glutathione pathway ( $G C L C$, panel A; GSR, panel B; GSS, panel C) in PMN isolated from mid-lactating dairy cows. Error bars represent SEM of the model estimate. Different letters (a-d) indicate significant differences among treatments $(P<0.05)$. GCLC, glutamate-cysteine ligase catalytic subunit; $G S R$, glutathione-disulfide reductase; $G S S$, glutathione synthetase.
$400 \mu \mathrm{g} / \mathrm{mL}$. The expression of $G C L C, G S R$, and $G S S$ was overall affected by the interaction L:M $\times$ Chol $(P$ $<0.05$; Figure 1). At $400 \mu \mathrm{g} / \mathrm{mL}$ Chol, GCLC expression was greater in PMNL incubated at an L:M of 2.9:1 compared with 3.6:1 $(P<0.05$; Figure $1 \mathrm{~A})$, at which point it was also lower compared with that at $0 \mu \mathrm{g} / \mathrm{mL}$ Chol $(P<0.05)$. In addition, for the L:M ratio of 2.9:1, $G C L C$ (Figure 1A), GSR (Figure 1B), and GSS (Figure 1C) had similar response patterns, with downregulation at the highest Chol concentration compared with 400 $\mu \mathrm{g} / \mathrm{mL}(P<0.05)$. A pattern similar to that of $G C L C$ was detected for GSR expression (Figure 1B), where incubation at L:M of 2.9:1 and 2.4:1 led to upregulation compared with an L:M of $3.6: 1$ at $400 \mu \mathrm{g} / \mathrm{mL}$ Chol $(P<0.05)$. Expression of $G S R$ was also lower at 400 and $800 \mu \mathrm{g} / \mathrm{mL}$ Chol compared with $0 \mu \mathrm{g} / \mathrm{mL}$ at an L:M ratio of $3.6: 1(P<0.05)$. Choline at $800 \mu \mathrm{g} / \mathrm{mL}$ downregulated $G S R$ expression compared with that at $400 \mu \mathrm{g} / \mathrm{mL}$ and an L:M ratio of 2.9:1 $(P<0.05)$. At an L:M of 3.6:1, GSS expression (Figure 1C) was downregulated when Chol supplementation increased from 0 to $400 \mu \mathrm{g} / \mathrm{mL}(P<0.05)$.

\section{Signaling and Cytokine Mediators}

Greater expression of $N R 3 C$ was reached at $400 \mu \mathrm{g} /$ $\mathrm{mL}$ Chol compared with 0 or $800 \mu \mathrm{g} / \mathrm{mL}$ (Quad, $P<$ 0.05; Table 1). Regarding Chol effects, NFKB1 expression was downregulated at $800 \mu \mathrm{g} / \mathrm{mL}$ compared with $400 \mu \mathrm{g} / \mathrm{mL}(P<0.05$; Table 1$)$ but similar to that at 0 $\mu \mathrm{g} / \mathrm{mL}(P>0.05$; Table 1$)$.

\section{Inflammatory Response}

Overall, Chol supplementation affected the expression of IL1B, IL10, and TNFA $(P<0.05$; Table 1$)$, leading to downregulation when supplemented at 400 or $800 \mu \mathrm{g} / \mathrm{mL}$ (Lin, $P<0.05$ ). Among genes related to inflammatory signaling and response and for L:M of 3.6:1, IL $1 B$ and IL6 expression was downregulated with increasing Chol supplementation, with the lowest expression at $800 \mu \mathrm{g} / \mathrm{mL}$ compared with L:M ratios of 2.9:1 and 2.4:1 for $I L 1 B(P<0.05$; Figure $2 \mathrm{~A})$. In addition, IL6 expression without Chol supplementation was higher at an L:M ratio of 3.6:1 compared with 2.9:1 and 2.6:1 $(P<0.05$; Figure 2B).

\section{Antimicrobial Function, Pattern Recognition, and Adhesion}

Among the genes involved in pattern recognition, expression of TLR2 was affected by L:M $(P<0.05$; Table 1). The effect of L:M was linear and quadratic, with greater expression when Met was increased to 


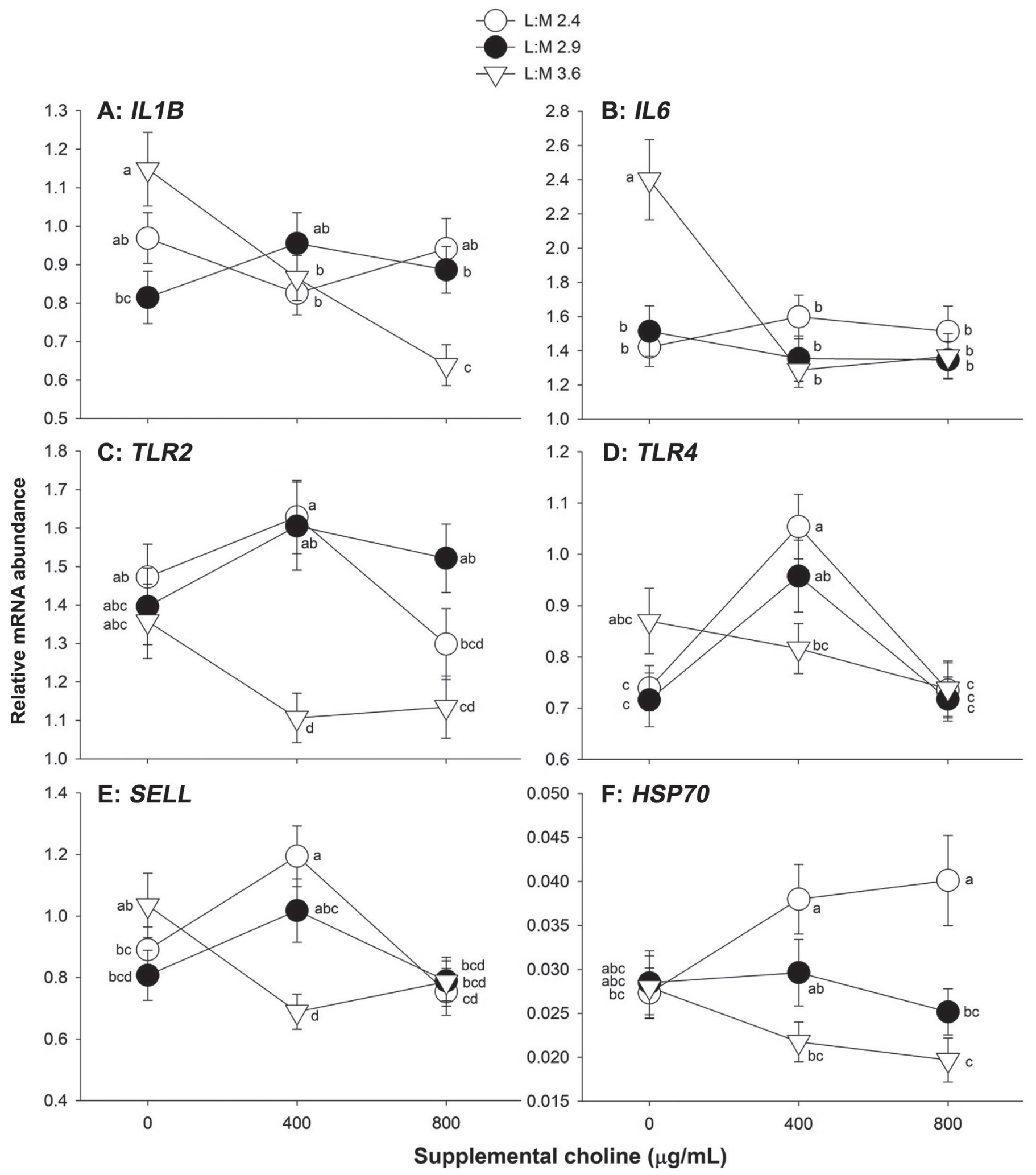

Figure 2. Interaction between Lys:Met (L:M) ratio (3.6, 2.9, 2.4) and supplemental choline (Chol; 0,400 , and $800 \mu \mathrm{g} / \mathrm{mL})$ in vitro on mRNA expression of genes associated with cytokines (IL1B, panel A; IL6, panel B), pattern recognition (TLR2, panel C; TLR4, panel D), adhesion (panel E, SELL), and apoptosis (HSP 70 , panel F) in PMN isolated from mid-lactating dairy cows. Error bars represent SEM of the model estimate. Different letters $(\mathrm{a}-\mathrm{d})$ indicate significant differences among treatments $(P<0.05)$. IL1B, IL-1 $\beta$; IL6, IL-6; TLR2, toll-like receptor 2; TLR4, toll-like receptor 4; SELL, L-selectin; HSPro, heat shock protein family A (Hsp70). 

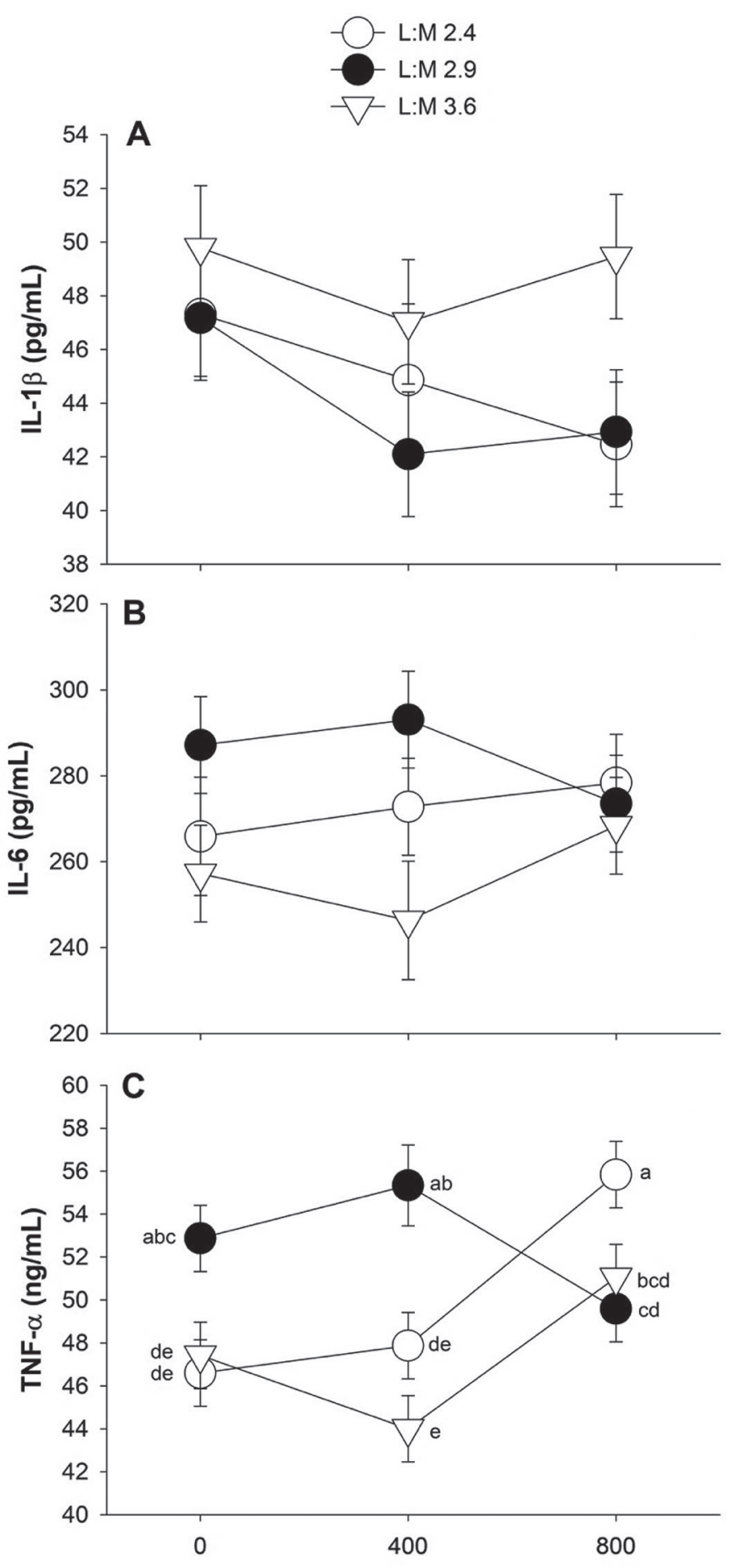

Supplemental choline $(\mu \mathrm{g} / \mathrm{mL})$

Figure 3. Interaction between Lys:Met (L:M) ratio (3.6, 2.9, 2.4) and supplemental choline (Chol; 0, 400, and $800 \mu \mathrm{g} / \mathrm{mL}$ ) in vitro on concentration of cytokines from supernatant of PMN isolated from mid-lactating dairy cows. Error bars represent SEM of the model estimate. Different letters (a-e) indicate significant differences among treatments $(P<0.05)$. reach an L:M ratio of 2.9:1 and remaining similar at L:M ratio of 2.4:1 (Lin and Quad, $P<0.05$; Table 1 ). Overall, Chol supplementation affected MPO, SOD1, and TLR $4(P<0.05$; Table 1$)$. Compared with no Chol supply, among genes involved in antimicrobial activity, Chol supply (400 or $800 \mu \mathrm{g} / \mathrm{mL}$ ) led to lower MPO ( $P$ $<0.05$ ), whereas expression of $L Y Z$ was quadratically affected $(P<0.05)$. A quadratic effect of Chol was also detected for SOD1 and TLR4, where Chol at $800 \mu \mathrm{g} /$ $\mathrm{mL}$ downregulated $S O D 1$ compared with Chol at 0 or $400 \mu \mathrm{g} / \mathrm{mL}$ and downregulated TLR 4 compared only with $400 \mu \mathrm{g} / \mathrm{mL}$ (Quad, $P<0.05$ ). The interaction L:M $\times$ Chol affected TLR2 and SELL expression $(P \leq$ $0.05)$. Indeed, within an L:M ratio of 3.6:1, Chol supply at $400 \mu \mathrm{g} / \mathrm{mL}$ caused lower expression of both TLR2 $(P<0.05$; Figure $2 \mathrm{C})$ and SELL $(P<0.05$; Figure $2 \mathrm{E})$ compared with L:M of 2.9 and $2.4: 1$, and compared with only 2.4:1 for TLR4 $(P<0.05$; Figure 2D). In addition, expression of SELL and TLR 4 was greater in PMNL incubated at L:M of 2.4:1 with $400 \mu \mathrm{g} / \mathrm{mL}$ of Chol compared with $800 \mu \mathrm{g} / \mathrm{mL}$ or no Chol. Especially for expression of TLR4, similar responses were obtained at L:M of 2.4:1 and 2.9:1 (Figure 2D). Choline supply at $800 \mu \mathrm{g} / \mathrm{mL}$ led to lower expression of TLR2 (Figure 2C) at an L:M ratio of 2.4:1 compared with 400 $\mu \mathrm{g} / \mathrm{mL}$ Chol, and PMNL incubated at an L:M ratio of 2.9:1 had higher TLR2 expression compared with L:M of $3.6: 1$ at $800 \mu \mathrm{g} / \mathrm{mL}$.

\section{Apoptosis and Cellular Stress}

Expression of $H S P 70$ was overall affected by L:M ( $P$ $<0.05$; Table 1), with greater expression detected at increasing levels of Met, specifically at 2.4:1 compared with 2.9:1 and 3.6:1 (Lin, $P<0.05$ ). In addition, Chol supplementation at 400 or $800 \mu \mathrm{g} / \mathrm{mL}$ upregulated $H S P 70$ at an L:M ratio of 2.4:1. That ratio of L:M led to the peak expression of $H S P^{7} 0$ at $800 \mu \mathrm{g} / \mathrm{mL}$ of Chol compared with other Chol concentrations and only compared with 3.6:1 L:M at $400 \mu \mathrm{g} / \mathrm{mL}(\mathrm{L}: \mathrm{M} \times$ Chol, $P<0.05$; Figure 2F). The expression of $B A X$ was downregulated at the highest Chol concentration $(800 \mu \mathrm{g} / \mathrm{mL})$ compared with 0 or $400 \mu \mathrm{g} / \mathrm{mL}$ (Lin, $P$ $<0.05$; Table 1).

\section{Supernatant Cytokine}

We detected an interaction L:M $\times$ Chol for TNF- $\alpha$ $(P<0.05$; Figure 3C), where Chol supply at $800 \mu \mathrm{g} /$ $\mathrm{mL}$ led to a higher response in PMNL incubated at L:M of 2.4:1 and 3.6:1 compared with Chol at $400 \mu \mathrm{g} / \mathrm{mL}$, whereas at an L:M of 2.9 and $800 \mu \mathrm{g} / \mathrm{mL}$ Chol resulted in lower TNF- $\alpha$ compared with $400 \mu \mathrm{g} / \mathrm{mL}$ Chol. 


\section{Principal Component Analysis}

Figures 4, 5, and 6 show the PCA results, Table 2 contains the loading vectors of all genes considered, and Figure 7 depicts the hierarchical clustering of gene expression data. The first $2 \mathrm{PC}$ explained $50.23 \%$ of total variation $(38.04 \%$ and $12.19 \%$ for PC1 and PC2, respectively). Overall, when only the Chol effect was considered in the plotting area (Figure 3), PC2 was able to separate the observations quite efficiently, according to supplemental Chol level $(0,400$, or $800 \mu \mathrm{g} /$ $\mathrm{mL})$. In fact, within PC2 that also was affected by Chol $(P<0.01)$, PMNL incubated with Chol at 400 or 800 $\mu \mathrm{g} / \mathrm{mL}$ had a different pattern from PMNL incubated without supplemental Chol (Figure $3 ; P<0.01$ ).

\section{DISCUSSION}

Molecular biology has revealed some mechanistic aspects underlying basic functions of immune cells during stressful periods in dairy cows (Weber et al., 2006; Moyes et al., 2014). As such, those tools can be applied to better understand the role of nutrition on immune function. By isolating PMNL cells from mid-lactating dairy cows and subjecting them to short-term incuba- tions with different levels of Met and Chol, we aimed to generate novel insights into how these nutritionally important methyl donors affect the innate immune system. Although a recent study from our group reported in vivo neutrophil mRNA data from cows receiving Met or Chol (Zhou et al., 2018), the Chol supplement fed in that study was later reported to have much lower bioavailability than expected (de Veth et al., 2016). Thus, it is imperative to generate data ascertaining what effects (if any) may be expected by enhancing the postruminal supply of Chol.

\section{Methionine Cycle}

Several benefits of feeding rumen-protected Met on improvements of production and health have been reported recently (Osorio et al., 2014; Zhou et al., 2016b; Batistel et al., 2018), with the Met cycle playing an important role from a physiologic standpoint. In the present study, the undetectable expression of PEMT, which catalyzes the formation of phosphatidylcholine upon binding the methyl group from S-adenosylmethionine to phosphatidylethanolamine, likely explains the inability of PMNL to use methyl groups to synthetize phosphatidylcholine, an important molecule in

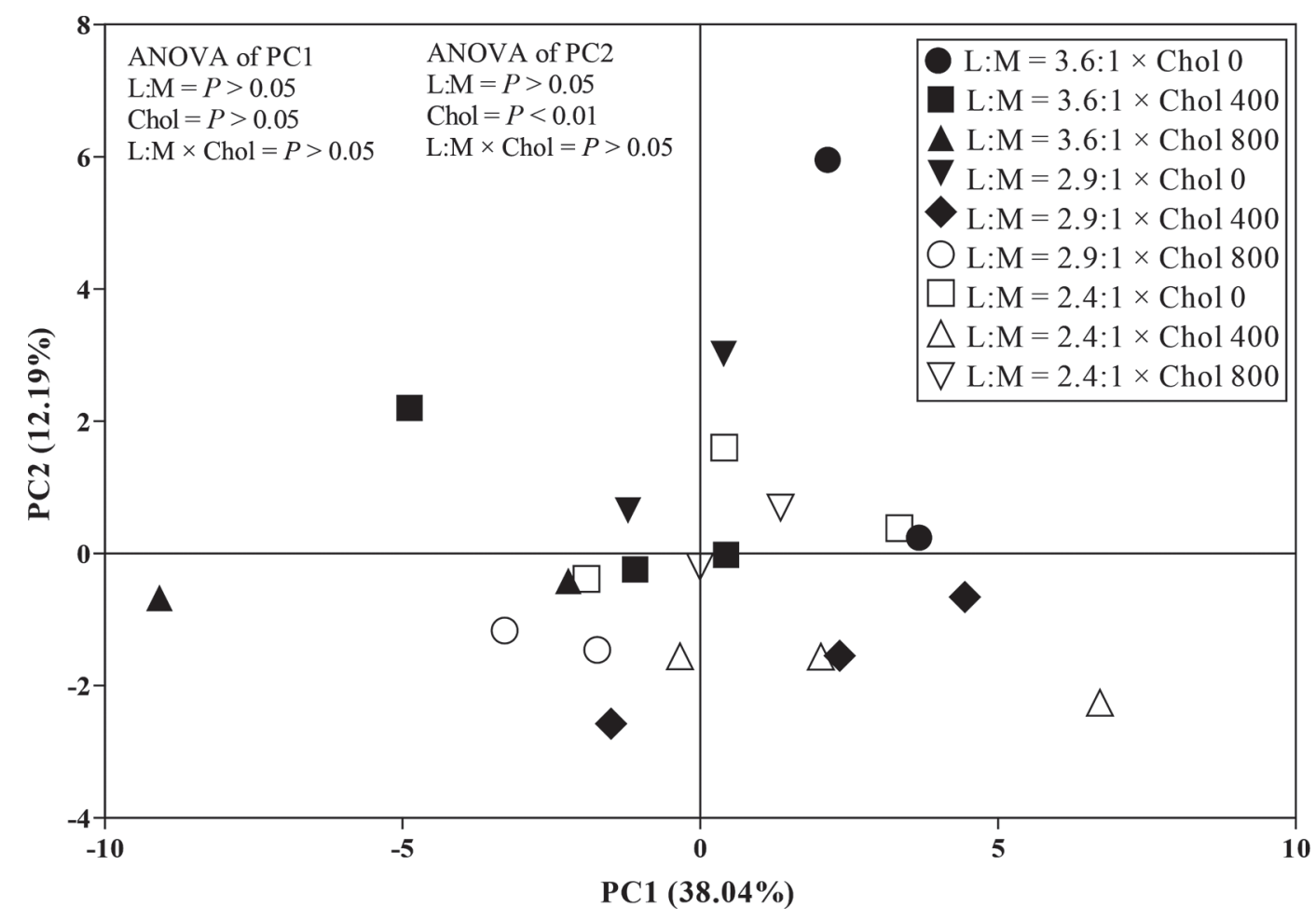

Figure 4. Scatterplot of the first 2 principal component (PC) scores of the principal components analysis model constructed to classify isolated non-stimulated blood PMN incubated in vitro with a Lys:Met (L:M) ratio of 3.6:1, 2.9:1, or 2.4:1 in combination with supplemental choline (Chol) at 0,400 , or $800 \mu \mathrm{g} / \mathrm{mL}$. The $\mathrm{x}$-axis represents component 1 (PC1) and the $\mathrm{y}$-axis represents component 2 (PC2). 


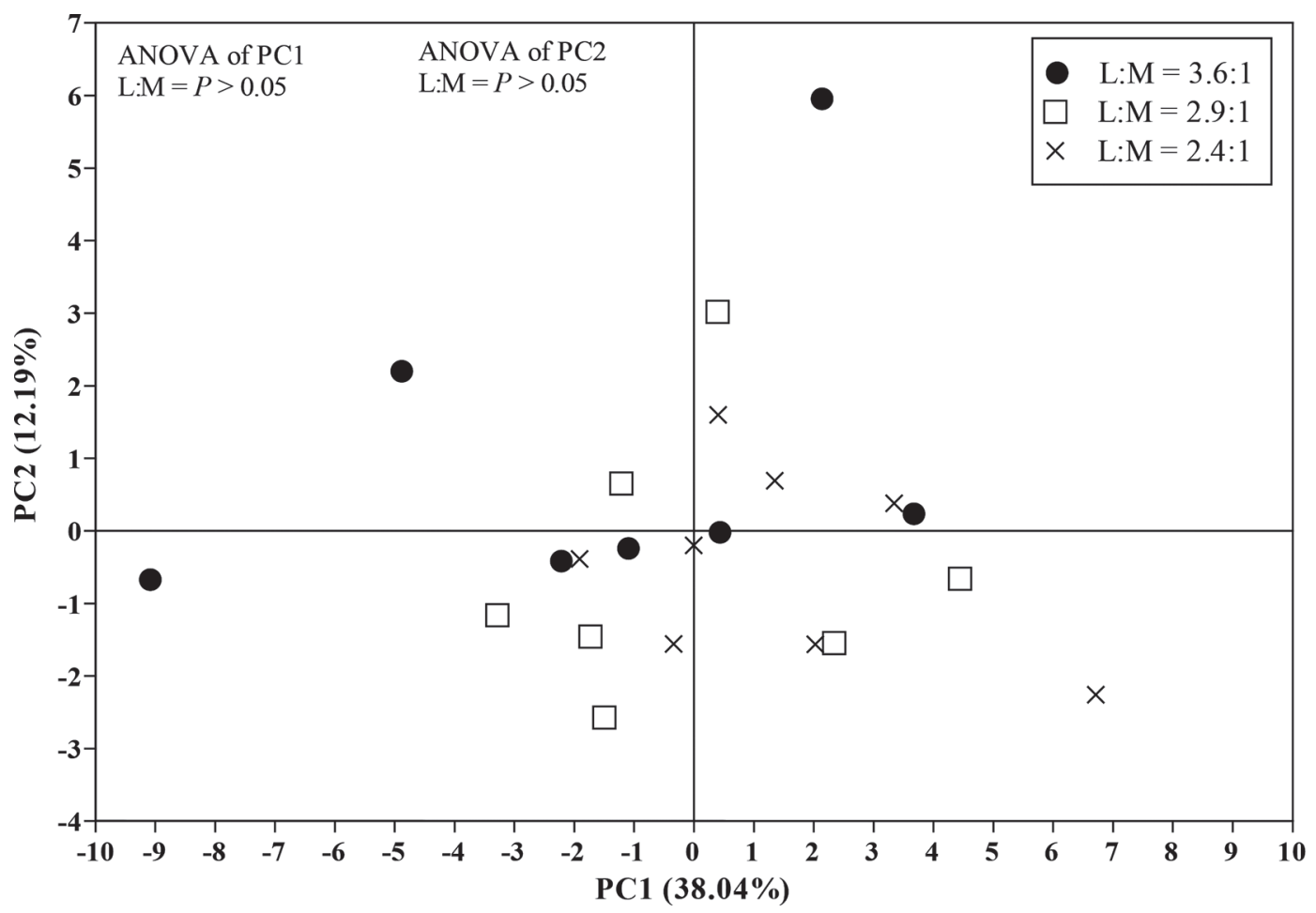

Figure 5. Scatterplot of the first 2 principal component (PC) scores of the principal components analysis constructed to classify isolated non-stimulated blood PMN incubated in vitro with a Lys:Met (L:M) ratio of 3.6:1, 2.9:1, or 2.4:1. The x-axis represents component 1 (PC1) and the y-axis represents component 2 (PC2).

leukocyte metabolism (Kim et al., 2007). Despite the fact we did not address this investigation toward genes related to the Kennedy pathway, it has recently been reported, for isolated bovine neutrophils under Chol in vitro treatment, that the abundance of choline kinase $\alpha$ ( $C H K A)$, the enzyme catalyzing the first step in phosphatidylcholine biosynthesis, was increased with Chol supplementation (Garcia et al., 2018). In fact, the main fate of Chol is the synthesis of phosphatidylcholine via the Kennedy pathway, which accounts for up to $95 \%$ of the total Chol pool in most tissues (Li and Vance, 2008; Gibellini and Smith, 2010).

To generate methyl groups for Met synthesis, Chol dehydrogenase $(\mathrm{CHDH})$ mediates the first and committed step in which Chol is first oxidized to betaine aldehyde. Subsequently, betaine aldehyde is further oxidized to betaine by betaine aldehyde dehydrogenase (BADH; Slow and Garrow, 2006). The fact that $C H D H$ and BHMT expression was undetectable is in line with our previous work on PMNL isolated from calves undergoing in vitro incubation with Met, Chol, and taurine (Abdelmegeid et al., 2017). Indeed, human- and bovinespecific research has noted that the betaine pathway is expressed only in liver and kidney (McKeever et al., 1991). Endogenous Met can be formed when homocysteine receives a methyl group from Chol through betaine or from 5-methyltetrahydrofolate through the tetrahydrofolate cycle ( $\mathrm{Li}$ and Vance, 2008; Mato et al., 2008). Given that betaine homocysteine methyltransferase (BHMT) is the key enzyme in transferring a methyl group from betaine to homocysteine to form Met, the lack of expression of BHMT led us to speculate that regeneration of Met through provision of methyl groups upon 5-methyltetrahydrofolate-homocysteine methyltransferase (MTR) activity (adding a methyl group to homocysteine from 5-methyltetrahydrofolate) could represent the main and probably the only pathway to regenerate Met in PMNL.

The linear increases in MAT2A (tendency) and MTR with increasing levels of Met (reducing L:M ratio) suggest a greater uptake of this AA from medium, and consequently greater provision of methyl groups that, via the folic cycle (MTR), could help regenerate Met from homocysteine. It is noteworthy that despite the absence of the betaine pathway (confirmed by the lack of expression of $C H D H$ and BHMT in our experiment), Chol supply up to $400 \mu \mathrm{g} / \mathrm{mL}$ was able to modulate the expression of MAT2A. Even though there are no previous reports in mammals, we speculate that the repression of MAT2A by Chol levels $>400 \mu \mathrm{g} / \mathrm{mL}$ might have been due to feedback inhibition. However, because $P E M T$ encodes an enzyme responsible for the forma- 
tion of phosphatidylcholine from phosphatidylethanolamine and S-adenosylmethionine, the lack of PEMT expression renders the interpretation of the Chol dose effect difficult (Stead et al., 2001; Jacobs et al., 2005). It is possible that when Chol is supplied above a certain level, the demand for methyl groups is reduced. On this basis, the current study offers a potential avenue for investigating alternative pathways involved in the use of methyl groups for the generation of phosphatidylcholine in bovine PMNL.

Despite additional Met seemingly being channeled through the cycle, as indicated by MAT2A and MTR, the expression of $S A H H$ indicated a different fate when the pool of available Met was at the highest level. In fact, at a L:M of 2.4:1, the lower $S A H H$ expression compared with 2.9:1 implied a reduced flux through homocysteine generation. This could be interpreted as a negative feedback response to counteract the toxicity of homocysteine as a consequence of its increasing levels (Jakubowski, 2004). In fact, these metabolic consequences of increased homocysteine concentrations limit the capacity for detoxification of excessive homocysteine by means of the reversal of the adenosylhomocysteinase reaction (Finkelstein, 1998). The lack of similar effect on $M T R$ could be explained by the fact that this enzyme regenerates methionine using a methyl group derived de novo from the one-carbon pathway (Cook et al., 1989).

In the present study, results for $A L D H Y A 1$ are in line with previous research from our group where this gene was investigated in calf PMNL at 2 wk of age (Abdelmegeid et al., 2017). This gene was originally investigated for its involvement in the betaine pathway, which allows Chol to contribute one of its methyl groups for the remethylation of homocysteine to Met. However, the undetectable expression of $C H D H$ and $B H M T$ leads us to hypothesize other major roles for $A L D H^{r} 7 A 1$ in PMNL; that is, in the immune response and cytoprotection against oxidative stress. The encoded protein is part of the aryl hydrocarbon receptor signaling cascade (Aleksunes and Klaassen, 2012), which influences the immune system in nonruminants (Stevens et al., 2009; Stockinger et al., 2011). It also has a direct role in cytoprotection against different stressors including oxidative stress (Brocker et al., 2011). Further research is required to assess the bovine-specific function of $A L$ $D H^{r} A 1$ in PMNL.

\section{Transsulfuration Pathway}

Together with expression of $C B S$, the lower expression of $C T H$ with Chol supply might indicate that Chol

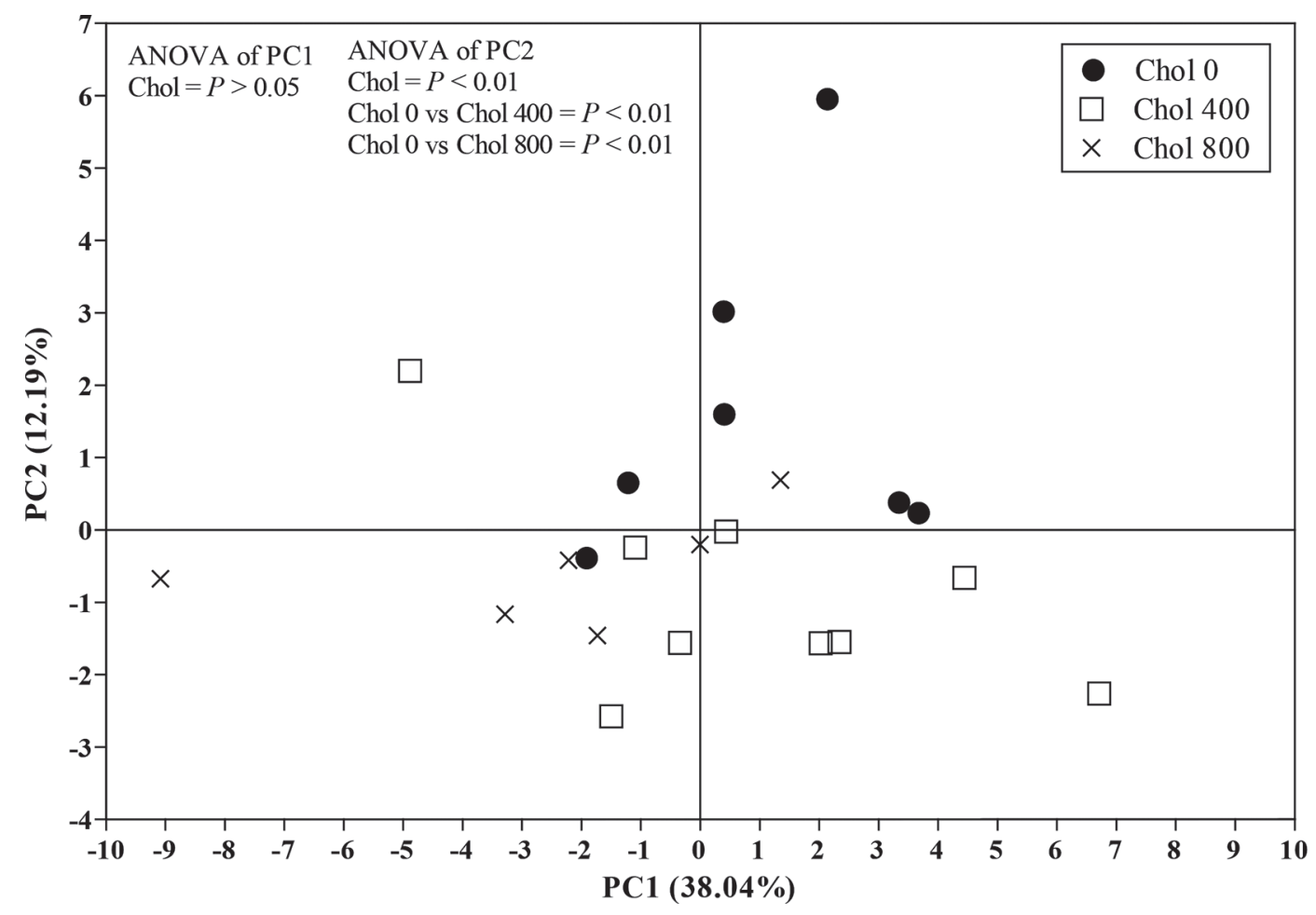

Figure 6. Scatterplot of the first 2 principal component (PC) scores of the principal components analysis model constructed to classify isolated non-stimulated blood PMN incubated in vitro with supplemental choline (Chol) at 0,400 , or $800 \mu \mathrm{g} / \mathrm{mL}$. The $\mathrm{x}$-axis represents component 1 (PC1) and the y-axis represents component 2 (PC2). 
is used mainly in the Kennedy pathway. The $C T H$ gene encodes the enzyme cystathionine gamma-lyase, responsible for the last step in forming cysteine, which in turn follows the metabolic pathway of glutathione (GSH) or taurine formation, both potent sulfur-containing antioxidants. It is noteworthy that Chol supplementation led to downregulation of genes involved in antimicrobial activity ( $M P O$ and $L Y Z$ ) and $S O D 1$. Such an effect suggests decreased production of $\mathrm{H}_{2} \mathrm{O}_{2}$, which supports the idea of a reduced oxidative stress status in PMNL.

Despite the fact that channeling of homocysteine (the sulfur carrier for GSH synthesis) to the transsulfuration pathway seemed to have been reduced by level of Chol supply, it appeared to improve the antioxidant status of PMNL, mainly through greater expression of $G C L C$ and GSR, when the Chol concentration was $400 \mu \mathrm{g} /$ $\mathrm{mL}$ and Met supply was pushed to achieve an L:M ratio of 2.9:1. That effect confirms, in part, our previous research with calf PMNL (Abdelmegeid et al., 2017). Regarding the overall effect of Met supply, the upregulation of GPX1 (encoding a major enzyme in the cellular GSH antioxidant system) with increasing levels of supplementation suggests an activation of the cytoprotective mechanisms against oxidative stress (Nordberg and Arnér, 2001). A benefit of GPX1 overexpression

Table 2. Loading vectors of genes submitted to principal component analysis for principal components (PC) 1 and 2

\begin{tabular}{lrc}
\hline Gene & PC1 & PC2 \\
\hline MAT2A & 0.16 & -0.35 \\
LYZ & 0.19 & -0.33 \\
NR3C1 & 0.22 & -0.24 \\
TLR2 & 0.19 & -0.22 \\
TLR4 & 0.20 & -0.18 \\
MTR & 0.27 & -0.14 \\
SELL & 0.20 & -0.13 \\
ALDH7A & 0.23 & -0.08 \\
GCLC & 0.16 & -0.07 \\
BCL2 & 0.18 & -0.07 \\
IRAK1 & 0.24 & -0.07 \\
NFKB1 & 0.25 & -0.07 \\
HSP70 & 0.23 & -0.04 \\
TNF & 0.07 & -0.01 \\
SOD1 & 0.17 & 0.04 \\
CTH & 0.19 & 0.06 \\
CDO1 & 0.14 & 0.07 \\
GPX1 & 0.09 & 0.08 \\
SAHH & 0.04 & 0.10 \\
IL10 & 0.16 & 0.11 \\
IL1B & 0.23 & 0.13 \\
CBS & 0.16 & 0.14 \\
CXCR1 & 0.01 & 0.14 \\
GSR & 0.19 & 0.15 \\
HAX & 0.17 & 0.22 \\
CSAD & 0.14 & 0.25 \\
IL6 & 0.16 & 0.26 \\
GSS & 0.17 & 0.27 \\
MPO & 0.22 & 0.29 \\
\hline & 0.12 & 0.35 \\
\hline
\end{tabular}

on the antioxidant defense enzymes has been reported in humans (Tome et al., 2005). Thus, in accordance with our recent findings on the alleviation of oxidative stress in cows supplemented with rumen-protected methionine (Batistel et al., 2018), upregulation of GPX1 might indicate a better overall status of PMNL when the L:M ratio was decreased.

\section{Inflammation}

Work in nonruminants has underscored that PMNL are no longer considered transcriptionally inert and that neutrophil pattern recognition receptor-mediated signaling is important for orchestrating innate and adaptive immunity via cytokine/chemokine production and the release of antimicrobials (Thomas and Schroder, 2013). In the current study, the lower expression of IL6 when the L:M ratio was $2.9: 1$ or $2.4: 1$ at any Chol concentration suggested an important modulatory effect by Met supply. However, an important role of Chol supply in reducing $I L 1 B$ and $I L 6$ expression was observed at an L:M ratio of 3.6:1, whereas no changes were observed when the L:M ratio was reduced to $2.9: 1$ or 2.4:1. These results suggest that at low levels of Met (L:M of 3.6:1), free Chol provided to PMNL cultures triggers an inflammatory modulation through acetylcholine receptors. In this respect, the cholinergic antiinflammatory pathway was proposed as a mechanism by which acetylcholine and Chol itself (considered as a natural selective agonist) attenuate systemic inflammatory responses via nicotinic receptors (Wang et al., 2003), whereas the muscarinic acetylcholine receptor was later identified as having the opposite effect on the inflammatory response of $\mathrm{T}$ cells (Razani-Boroujerdi et al., 2008).

In a recent study investigating the effect of increased Chol concentrations in cultures of bovine innate and adaptive immune cells, Garcia et al. (2018) observed greater expression of nicotinic acetylcholine receptor compared with muscarinic receptors in monocytes and neutrophils coupled with an anti-inflammatory effect that has also been confirmed in previous studies (Wang et al., 2003; Parrish et al., 2008). In fact, the anti-inflammatory efficacy of Chol reported in vivo (murine model involving nicotinic acetylcholine receptor-knockout mice during endotoxemia) and in vitro (endotoxin-activated macrophages) demonstrates that the suppression of TNF- $\alpha$ release by Chol requires nicotinic acetylcholine receptor-mediated signaling.

The downregulation of NFKB1 and NR3C1 (transcription factors involved in the inflammatory cascade) with increasing Chol supply from 400 to $800 \mu \mathrm{g} / \mathrm{mL}$ was in agreement with Parrish et al. (2008), where endotoxin-activated macrophage-like cells treated 


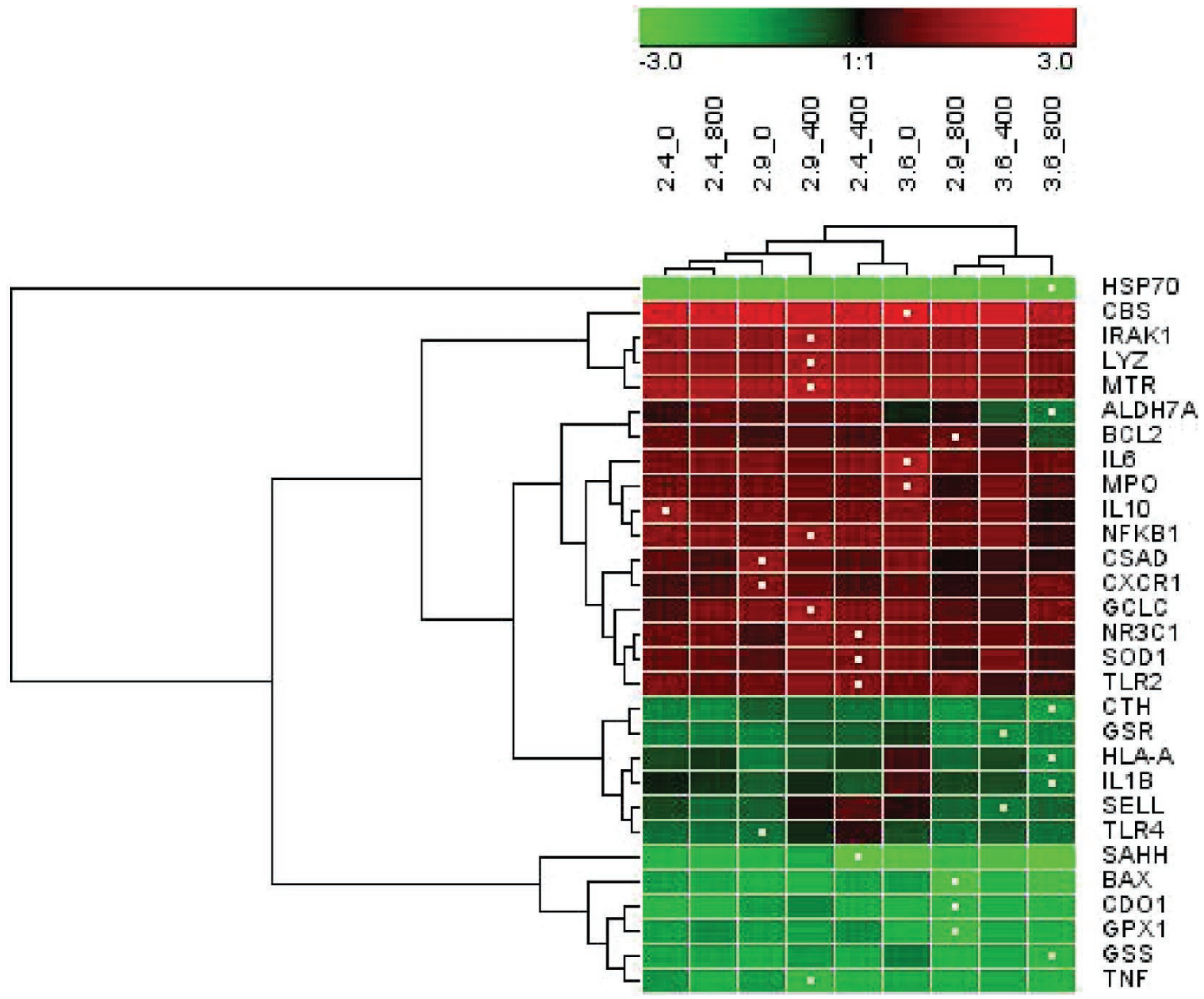

Figure 7. Hierarchical clustering of gene expression data for each treatment relative to the control. Dendrograms allow visualization of clusters of similarity in expression pattern among genes between treatments (links denoted by the lines at the left side of the picture), or among treatments between genes (denoted by the lines at the top of the figure). Cutoffs for expression level are denoted by shades of green and red according to the intensity bar at the top of the figure. Red intensity denotes an increase and green intensity a decrease in expression. White dots denote the largest responses (up or down) in mRNA expression for each gene.

with Chol had a significant inhibition of nuclear factor $(\mathbf{N F})-\kappa \mathrm{B}$ activation together with the reduction of TNF- $\alpha$. However, the lack of these effects, in terms of higher anti-inflammatory response via the reduced expression of IL6,IL1B, NFKB1, and NR3C1, when Chol supply was coupled with increasing levels of Met remains unclear.

\section{Pattern Recognition, Adhesion, Antimicrobial Function, and Cellular Stress}

Enhancing the supply of Met can activate the immune response of monocytes and neutrophils in cows (Osorio et al., 2014; Zhou et al., 2016a). The current study revealed a modulatory effect of Met on the expression of cytokines and the TLR upstream receptors (TLR2 and $T L R 4$ ). The lower expression of proinflammatory cytokines supports a low level of activation of the PMNL but also an improved PMNL pathogen-recognition mechanism (greater TLR2 and TLR4) when PMNL received $400 \mu \mathrm{g} / \mathrm{mL}$ Chol. Unexpectedly, the addition of Chol at an L:M ratio of 3.6:1 caused downregulation of SELL and TLR2, despite the fact that, together with increasing Met inclusion, Chol led to a greater expression of toll-like receptor mechanism. We speculate that Chol provision over the basal medium content coupled with a higher L:M ratio leads to reduced expression of the inflammatory response because of lower activation of the TLR pathway, responsible for activating NF- $\mathrm{B}$ signaling pathways, which results in the production of inflammatory cytokines (Lee and Kim, 2007). However, other genes encompassing the migration/adhesion and downstream signaling of pattern recognition receptors should be investigated to further explore the controversial effect reported herein.

Administration of Chol in humans and rodents attenuates oxidative stress by downregulating $N F-\kappa B$ activity and production of reactive oxygen species (ROS), thus modulating its anti-inflammatory effect partly through the redox status of the cell (Mehta et al., 
2009, 2010). This latter finding agrees with results in the present study in which Chol supply clearly caused a lower expression of $S O D 1$ and $M P O$. Because oxidative stress and inflammatory events are often interrelated (Sordillo and Mavangira, 2014), the lower expression of $S O D 1$ and $M P O$ (causing the production of ROS during phagocytosis) probably contributes to the restored expression of all inflammatory signaling molecules (IL6, IL1B, NFKB1, and NR3C1).

Apoptosis is the most thoroughly characterized form of programmed cell death and a wide variety of apoptotic signals, including growth factor deprivation, hypoxia, oxidative stress, and DNA damage, trigger apoptosis (Edinger and Thompson, 2004). Heat shock protein (HSP)70 is a highly inducible HSP with cytoprotective properties. It participates in the regulation of apoptosis passing through the immune system, regulating enzymatic activity, and affecting related gene expression (Jäättelä, 1999). At least in nonruminants, Met is a promising inducer of HSP, as it can increase HSP70 expression during heat stress, oxidative stress, and other stress states in cells or tissues (Zhou et al., 2010). Recently, Han et al. (2015) reported that after $24 \mathrm{~h}$ of culturing bovine mammary epithelial cells with Met, the expression of $H S P^{r} 0$ was higher and inhibited heat stress-induced apoptosis while increasing cell viability. Hence, supplying Met especially under severe stress can enhance the capability of resisting and consequently protecting cells.

Although a large number of genes are reported to be involved in the regulation of apoptotic cell death, $B C L 2$ and related family member $B A X$ play a major role in regulating apoptotic cell death in response to inflammation (Nakamura et al., 2000). Reactive oxygen molecules released from activated PMNL are involved in the induction of apoptosis (Yang et al., 1996). The fact that Chol exerted a linear reduction of $B A X$ expression at increasing Chol supply levels supports the idea that this methyl donor can reduce production of ROS and inflammatory signals. The mechanism by which Chol and Met directly or indirectly modulate cell survival needs to be clarified.

\section{Principal Components Analysis}

Multivariate analysis is a robust statistical approach to analyze interrelationships between a large number of variables. The approach condenses the information of original variables into a new and smaller set of latent factors while minimizing the loss of information. In the last decade, the multivariate analysis approach has become more interesting, particularly with the availability of large databases obtained by omics technologies. In the current study, PCA revealed 2 dis- tinct clusters when only Chol was taken into account. In fact, no supplemental Chol and supplemental Chol (400 and $800 \mu \mathrm{g} / \mathrm{mL}$ ) clusters were separated by PC2 (Figure $6 ; \mathrm{y}$-axis). Thus, in addition to other sources of variation, a specific gene expression signature exists for PMNL supplemented with Chol compared with unsupplemented controls, which was also supported by the cluster analysis (Figure 7). Furthermore, the cluster analysis, in contrast to the PCA, highlighted a general interaction between Chol and Met supplementation. Two major clusters (dendrogram at top of Figure 7), in fact, were generated, dividing the samples between those with high Met and low Chol (to the left), and those with low Met and high Chol (to the right).

\section{Limitations}

The current study design allowed us to identify molecular effects of Met or Chol supplementation, or both, on inflammation and oxidative stress gene networks in lactating Holstein cow PMNL. However, 2 limitations will have to be addressed in future experiments: (1) the low purity of the PMNL population, and (2) the need to pool cells from different donor cows. The extraction procedure used normally yields cell populations with greater than $90 \%$ purity and viability, but when performed on multiple animals at a time (i.e., more than 2-3 donors), its performance suffers. The implementation of density gradient isolation would help not only to increase purity and viability of the final population of PMNL, but also to reduce time from sampling to incubation, while increasing the yield per donor animal. This would address the second limitation as well. By increasing the yield per donor, a large-enough population for complex in vitro designs would be achieved, thereby reducing the risk of cross stimulation between cells of different donors. Increasing the blood draw volume would also help increase the yield.

\section{CONCLUSIONS}

Pathways associated with inflammatory signaling and activation, antioxidant balance, and cell survival in nonactivated PMNL are responsive to enhanced supply of methyl donors. Although a positive effect on cell function was inferred by alterations in mRNA abundance, oversupply alters the Met cycle with a consequent impairment in the formation of methyl groups. Together, these responses suggest the existence of cytotoxicity thresholds. Further research will be needed to better explore the beneficial effect of methyl donor supplementation on PMNL, including effective doses in vivo. 


\section{REFERENCES}

Abdelmegeid, M. K., M. Vailati-Riboni, A. Alharthi, F. Batistel, and J. J. Loor. 2017. Supplemental methionine, choline, or taurine alter in vitro gene network expression of polymorphonuclear leukocytes from neonatal Holstein calves. J. Dairy Sci. 100:3155-3165. https://doi.org/10.3168/jds.2016-12025.

Aleksunes, L. M., and C. D. Klaassen. 2012. Coordinated regulation of hepatic phase I and II drug-metabolizing genes and transporters using AhR-, CAR-, PXR-, PPAR $\alpha-$, and Nrf2-null mice. Drug Metab. Dispos. 40:1366-1379. https://doi.org/10.1124/dmd.112 .045112 .

Batistel, F., J. M. Arroyo, C. I. M. Garces, E. Trevisi, C. Parys, M. A. Ballou, F. C. Cardoso, and J. J. Loor. 2018. Ethyl-cellulose rumen-protected methionine alleviates inflammation and oxidative stress and improves neutrophil function during the periparturient period and early lactation in Holstein dairy cows. J. Dairy Sci. 101:480-490. https://doi.org/10.3168/jds.2017-13185.

Brocker, C., M. Cantore, P. Failli, and V. Vasiliou. 2011. Aldehyde dehydrogenase 7A1 (ALDH7A1) attenuates reactive aldehyde and oxidative stress induced cytotoxicity. Chem Biol. Interact. 191:269-277. https://doi.org/10.1016/j.cbi.2011.02.016.

Cook, R. J., D. W. Horne, and C. Wagner. 1989. Effect of dietary methyl group deficiency on one-carbon metabolism in rats. J. Nutr. 119:612-617. https://doi.org/10.1093/jn/119.4.612.

de Veth, M. J., V. M. Artegoitia, S. R. Campagna, H. Lapierre, F. Harte, and C. L. Girard. 2016. Choline absorption and evaluation of bioavailability markers when supplementing choline to lactating dairy cows. J. Dairy Sci. 99:9732-9744. https://doi.org/10.3168/ jds.2016-11382.

Du, X., T. Shen, H. Wang, X. Qin, D. Xing, Q. Ye, Z. Shi, Z. Fang, Y. Zhu, Y. Yang, Z. Peng, C. Zhao, B. Lv, X. Li, G. Liu, and X. Li. 2018. Adaptations of hepatic lipid metabolism and mitochondria in dairy cows with mild fatty liver. J. Dairy Sci. 101:9544-9558.

Edinger, A. L., and C. B. Thompson. 2004. Death by design: Apoptosis, necrosis and autophagy. Curr. Opin. Cell Biol. 16:663-669. https://doi.org/10.1016/j.ceb.2004.09.011.

Fear, J. M., and P. J. Hansen. 2011. Developmental changes in expression of genes involved in regulation of apoptosis in the bovine preimplantation embryo. Biol. Reprod. 84:43-51. https://doi.org/ 10.1095/biolreprod.110.086249.

Finkelstein, J. D. 1998. The metabolism of homocysteine: pathways and regulation. Eur. J. Pediatr. 157(Suppl. 2):S40-S44. https:// doi.org/10.1007/PL00014300.

Garcia, M., L. K. Mamedova, B. Barton, and B. J. Bradford. 2018. Choline regulates the function of bovine immune cells and alters the mRNA abundance of enzymes and receptors involved in its metabolism in vitro. Front. Immunol. 9:2448. https://doi.org/10 .3389/fimmu.2018.02448.

Gibellini, F., and T. K. Smith. 2010. The Kennedy pathway-de novo synthesis of phosphatidylethanolamine and phosphatidylcholine. IUBMB Life 62:414-428. https://doi.org/10.1002/iub.337.

Han, Z. Y., T. Mu, and Z. Yang. 2015. Methionine protects against hyperthermia-induced cell injury in cultured bovine mammary epithelial cells. Cell Stress Chaperones 20:109-120. https://doi.org/ 10.1007/s12192-014-0530-7.

Ingvartsen, K. L., and K. Moyes. 2013. Nutrition, immune function and health of dairy cattle. Animal 7:112-122. https://doi.org/10 $.1017 /$ S175173111200170X.

Jäättelä, M. 1999. Heat shock proteins as cellular lifeguards. Ann. Med. 31:261-271. https://doi.org/10.3109/07853899908995889.

Jacobs, R. L., L. M. Stead, C. Devlin, I. Tabas, M. E. Brosnan, J. T. Brosnan, and D. E. Vance. 2005. Physiological regulation of phospholipid methylation alters plasma homocysteine in mice. J. Biol. Chem. 280:28299-28305. https://doi.org/10.1074/jbc .M501971200.

Jakubowski, H. 2004. Molecular basis of homocysteine toxicity in humans. Cell. Mol. Life Sci. 61:470-487. https://doi.org/10.1007/ s00018-003-3204-7.

Kim, S. W., R. D. Mateo, Y. L. Yin, and G. Wu. 2007. Functional amino acids and fatty acids for enhancing production performance of sows and piglets. Asian-australas. J. Anim. Sci. 20:295-306. https://doi.org/10.5713/ajas.2007.295.

Lee, M. S., and Y.-J. Kim. 2007. Signaling pathways downstream of pattern-recognition receptors and their cross talk. Annu. Rev. Biochem. 76:447-480. https://doi.org/10.1146/annurev.biochem.76 .060605 .122847

Li, X., W. Huang, J. Gu, X. Du, L. Lei, X. Yuan, G. Sun, Z. Wang, X. Li, and G. Liu. 2015. SREBP-1c overactivates ROS-mediated hepatic NF- $\mathrm{B}$ inflammatory pathway in dairy cows with fatty liver. Cell. Signal. 27:2099-2109.

Li, Z., and D. E. D. E. Vance. 2008. Phosphatidylcholine and choline homeostasis. J. Lipid Res. 49:1187-1194. https://doi.org/10.1194/ jlr.R700019-JLR200.

Loor, J. J., M. Bionaz, and J. K. Drackley. 2013. Systems physiology in dairy cattle: Nutritional genomics and beyond. Annu. Rev. Anim. Biosci. 1:365-392. https://doi.org/10.1146/annurev-animal $-031412-103728$.

Mato, J. M., M. L. Martínez-Chantar, and S. C. Lu. 2008. Methionine metabolism and liver disease. Annu. Rev. Nutr. 28:273-293. https: //doi.org/10.1146/annurev.nutr.28.061807.155438.

McKeever, M. P., D. G. Weir, A. Molloy, and J. M. Scott. 1991. Betaine-homocysteine methyltransferase: organ distribution in man, pig and rat and subcellular distribution in the rat. Clin. Sci. (Lond.) 81:551-556. https://doi.org/10.1042/cs0810551.

Mehta, A. K., N. Arora, S. N. Gaur, and B. P. Singh. 2009. Choline supplementation reduces oxidative stress in mouse model of allergic airway disease. Eur. J. Clin. Invest. 39:934-941. https://doi .org/10.1111/j.1365-2362.2009.02190.x.

Mehta, A. K., B. P. Singh, N. Arora, and S. N. Gaur. 2010. Choline attenuates immune inflammation and suppresses oxidative stress in patients with asthma. Immunobiology 215:527-534. https://doi org/10.1016/j.imbio.2009.09.004.

Moyes, K. M., D. E. Graugnard, M. J. Khan, M. Mukesh, and J. J. Loor. 2014. Postpartal immunometabolic gene network expression and function in blood neutrophils are altered in response to prepartal energy intake and postpartal intramammary inflammatory challenge1. J. Dairy Sci. 97:2165-2177. https://doi.org/10.3168/ jds.2013-7433.

Nakamura, M., N. P. Wang, Z. Q. Zhao, J. N. Wilcox, V. Thourani, R. A. Guyton, and J. Vinten-Johansen. 2000. Preconditioning decreases Bax expression, PMN accumulation and apoptosis in reperfused rat heart. Cardiovasc. Res. 45:661-670. https://doi.org/ 10.1016/s0008-6363(99)00393-4.

Nordberg, J., and E. S. J. Arnér. 2001. Reactive oxygen species, antioxidants, and the mammalian thioredoxin system. Free Radic. Biol. Med. 31:1287-1312. https://doi.org/10.1016/S0891-5849(01)00724 -9 .

Osorio, J. S., P. Ji, J. K. Drackley, D. Luchini, and J. J. Loor. 2014. Smartamine M and MetaSmart supplementation during the peripartal period alter hepatic expression of gene networks in 1-carbon metabolism, inflammation, oxidative stress, and the growth hormone-insulin-like growth factor 1 axis pathways. J. Dairy Sci. 97:7451-7464. https://doi.org/10.3168/jds.2014-8680.

Parrish, W. R., M. Rosas-Ballina, M. Gallowitsch-Puerta, M. Ochani, K. Ochani, L.-H. Yang, L. Hudson, X. Lin, N. Patel, S. M. Johnson, S. Chavan, R. S. Goldstein, C. J. Czura, E. J. Miller, Y. Al-Abed, K. J. Tracey, and V. Pavlova. 2008. Modulation of TNF release by choline requires alpha7 subunit nicotinic acetylcholine receptor-mediated signaling. Mol. Med. 14:567-574. https://doi .org/10.2119/2008-00079.Parrish.

Razani-Boroujerdi, S., M. Behl, F. F. Hahn, J. C. Pena-Philippides, J. Hutt, and M. L. Sopori. 2008. Role of muscarinic receptors in the regulation of immune and inflammatory responses. J. Neuroimmunol. 194:83-88. https://doi.org/10.1016/j.jneuroim.2007.11.019.

Slow, S., and T. A. Garrow. 2006. Liver choline dehydrogenase and kidney betaine-homocysteine methyltransferase expression are not affected by methionine or choline intake in growing rats. J. Nutr. 136:2279-2283.

Sordillo, L. M., and V. Mavangira. 2014. The nexus between nutrient metabolism, oxidative stress and inflammation in transition cows. Anim. Prod. Sci. 54:1204-1214. https://doi.org/10.1071/AN14503. 
Stead, L. M., K. P. Au, R. L. Jacobs, M. E. Brosnan, and J. T. Brosnan. 2001. Methylation demand and homocysteine metabolism: Effects of dietary provision of creatine and guanidinoacetate. Am. J. Physiol. Endocrinol. Metab. 28:E1095-E1100. https://doi.org/ 10.1152/ajpendo.2001.281.5.E1095

Stevens, E. A., J. D. Mezrich, and C. A. Bradfield. 2009. The aryl hydrocarbon receptor: A perspective on potential roles in the immune system. Immunology 127:299-311. https://doi.org/10.1111/ j.1365-2567.2009.03054.x.

Stockinger, B., K. Hirota, J. Duarte, and M. Veldhoen. 2011. External influences on the immune system via activation of the aryl hydrocarbon receptor. Semin. Immunol. 23:99-105. https://doi.org/10 .1016/j.smim.2011.01.008.

Sturn, A., J. Quackenbush, and Z. Trajanoski. 2002. Genesis: Cluster analysis of microarray data. Bioinformatics 18:207-208. https:// doi.org/10.1093/bioinformatics/18.1.207.

Thomas, C. J., and K. Schroder. 2013. Pattern recognition receptor function in neutrophils. Trends Immunol. 34:317-328. https://doi .org/10.1016/j.it.2013.02.008

Tome, M. E., D. B. F. Johnson, L. M. Rimsza, R. A. Roberts, T. M. Grogan, T. P. Miller, L. W. Oberley, and M. M. Briehl. 2005. A redox signature score identifies diffuse large B-cell lymphoma patients with a poor prognosis. Blood 106:3594-3601. https://doi .org/10.1182/blood-2005-02-0487.

Vailati-Riboni, M., Z. Zhou, C. B. Jacometo, A. Minuti, E. Trevisi, D. N. Luchini, and J. J. Loor. 2017. Supplementation with rumenprotected methionine or choline during the transition period influences whole-blood immune response in periparturient dairy cows. J. Dairy Sci. 100:3958-3968. https://doi.org/10.3168/jds.2016 -11812 .

Wang, H., M. Yu, M. Ochani, C. A. Amelia, M. Tanovic, S. Susarla, J. H. Li, H. Wang, N. Yang, L. Ulloa, Y. Al-Abed, C. J. Czura, and K. J. Tracey. 2003. Nicotinic acetylcholine receptor $\alpha 7$ subunit is an essential regulator of inflammation. Nature 421:384-388. https: //doi.org/10.1038/nature01339.

Weber, P. S. D., S. A. Madsen-Bouterse, G. J. M. Rosa, S. Sipkovsky, X. Ren, P. E. Almeida, R. Kruska, R. G. Halgren, J. L. Barrick, and J. L. Burton. 2006. Analysis of the bovine neutrophil transcriptome during glucocorticoid treatment. Physiol. Genomics 28:97-112. https://doi.org/10.1152/physiolgenomics.00094.2006.
Yang, J. J., R. Kettritz, R. J. Falk, J. C. Jennette, and M. L. Gaido. 1996. Apoptosis of endothelial cells induced by the neutrophil serine proteases proteinase 3 and elastase. Am. J. Pathol. 149:16171626. https://doi.org/10.1080/09585192.2013.870292.

Zenobi, M. G., R. Gardinal, J. E. Zuniga, A. L. G. Dias, C. D. Nelson, J. P. Driver, B. A. Barton, J. E. P. Santos, and C. R. Staples. 2018. Effects of supplementation with ruminally protected choline on performance of multiparous Holstein cows did not depend upon prepartum caloric intake. J. Dairy Sci. 101:1088-1110. https://doi .org/10.3168/jds.2017-13327.

Zhou, Z., R. Cui, J. Wang, H. Wei, D. Bu, H. Hu, and L. Zhou. 2010 Cell growth, apoptosis and the mRNA transcription of heat shock protein: Effects of heat stress on bovine mammary epithelial cells. Acta Vet. Zootech. Sin. 41:600-607.

Zhou, Z., O. Bulgari, M. Vailati-Riboni, E. Trevisi, M. A. Ballou, F. C. Cardoso, D. N. Luchini, and J. J. Loor. 2016a. Rumen-protected methionine compared with rumen-protected choline improves immunometabolic status in dairy cows during the peripartal period. J. Dairy Sci. 99:8956-8969. https://doi.org/10.3168/jds.2016 $-10986$.

Zhou, Z., F. Ferdous, P. Montagner, D. N. Luchini, M. N. Corrêa, and J. J. Loor. 2018. Methionine and choline supply during the peripartal period alter polymorphonuclear leukocyte immune response and immunometabolic gene expression in Holstein cows. J. Dairy Sci. 101:10374-10382. https://doi.org/10.3168/jds.2018-14972.

Zhou, Z., M. Vailati-Riboni, D. N. Luchini, and J. J. Loor. 2016b. Methionine and choline supply during the periparturient period alter plasma amino acid and one-carbon metabolism profiles to various extents: Potential role in hepatic metabolism and antioxidant status. Nutrients 9:E10. https://doi.org/10.3390/nu9010010.

Zhou, Z., M. Vailati-Riboni, E. Trevisi, J. K. Drackley, D. N. Luchini, and J. J. Loor. 2016c. Better postpartal performance in dairy cows supplemented with rumen-protected methionine compared with choline during the peripartal period. J. Dairy Sci. 99:8716-8732. https://doi.org/10.3168/jds.2015-10525.

Zhu, Y., G. Liu, X. Du, Z. Shi, M. Yin, X. Sha, X. Li, Z. Wang, and X. Li. 2019. Expression patterns of hepatic genes involved in lipid metabolism in cows with subclinical or clinical ketosis. J. Dairy Sci. 102:1725-1735. 